\title{
Evaluation of in vitro activity and SAR study of the novel hetarylamino-3-aryl- $1 H$-indazole derivatives as inhibitors of protein kinase CK2
}

\author{
M. V. Protopopov ${ }^{1}$, V. S. Vdovin ${ }^{1}$, S. S. Lukashov ${ }^{1}$, O. V. Ostrynska ${ }^{1}$, \\ I. P. Borysenko ${ }^{1,2}$, O. V. Borovykov ${ }^{1}$, S. A. Starosyla', Y. V. Bilokin ${ }^{3}$, \\ O. P. Kukharenko ${ }^{1}$, V. G. Bdzhola ${ }^{1}$, S. M. Yarmoluk ${ }^{1}$ \\ ${ }^{1}$ Institute of Molecular Biology and Genetics of NASU, \\ 150, Zabolotnogo Str., Kyiv, Ukraine, 03143. \\ ${ }^{2}$ LLC Scientific and service firm "Otava", \\ 117/125 Borschagivska St., Suite 79, 03056, Kyiv, Ukraine \\ ${ }^{3}$ OTAVA Ltd., 400 Applewood Crescent, \\ Unit 100, Vaughan, Ontario, L4K 0C3 Canada \\ mykola.protopopov@imbg.org.ua.
}

\begin{abstract}
Aim. To identify novel protein kinase CK2 inhibitors among the 5-hetarylamino-1H-indazoles. Methods. Biochemical testing was carried out with the aid of $\gamma_{-3}{ }^{32} \mathrm{P}$ ATP in vitro kinase assay. Molecular docking via the Autodock 4.2.6 program package was executed, rescoring of docking results was performed using DrugScore scoring function. Results. Among the 17 studied 5-amino-3-arylindazole derivatives 11 inhibitors of protein kinase $\mathrm{CK} 2$ with $\mathrm{IC}_{50}$ in nanomolar range were identified. The most active compound has $\mathrm{IC}_{50}=2 \mathrm{nM}$. SAR study and additional molecular modeling of these compounds allowed us to select prospective substituents for construction of novel compounds with improved activity and physicochemical properties. Conclusions. As a result of this work 11 nanomolar protein kinase CK2 inhibitors were developed and the binding modes of these compounds with the ATP-acceptor site were proposed using molecular docking methods. The physicochemical properties and SAR of substituents of studied compounds were analyzed and 6 novel compounds were designed for further development as protein kinase CK2 inhibitors. Summarizing, 5-heterylamino-1H-indazoles are a good basis for further CK2 inhibitors development.
\end{abstract}

Ke y w o r d s: protein kinase CK2 inhibitor, in vitro kinase assay, molecular docking, indazole, pyrazolo[3,4-d]pyrimidine.

(C) 2021 M. V. Protopopov et al.; Published by the Institute of Molecular Biology and Genetics, NAS of Ukraine on behalf of Biopolymers and Cell. This is an Open Access article distributed under the terms of the Creative Commons Attribution License (http://creativecommons.org/licenses/by/4.0/), which permits unrestricted reuse, distribution, and reproduction in any medium, provided the original work is properly cited 


\section{Introduction}

Serine/threonine protein kinase CK2 was discovered among the first ones in 1954 [1]. Despite a long history of CK2 investigations, a number of its functions are not completely determined. At the same time CK2 has unique properties that differ it from the majority of protein kinases [2]. In contrast to the common protein kinases CK2 cannot be turned off by the mechanisms such as phosphorylation or dephosphorylation, second messenger binding and reversible association with regulatory subunits, but can be only "modulated" by means of the mechanisms, which are still not completely understood [3]. Unlike the most of other oncogenic protein kinases, the malignant behavior of CK2 is not caused by deregulation of the kinase activity at a genetic level. CK2 has the unique ability to use GTP as well as ATP as the phosphate donors [4]. The ATP binding pocket of CK2 is smaller than that of the other protein kinases, that is why the ATP competitive inhibitors with higher selectivity for CK2 could be developed. CK2 has high pleiotropicity (CK2 phosphorylates more than 500 proteins) [5] - most of the substrates have been found to be transcriptional factors (60), effectors of DNA/RNA structure (50), signaling proteins (more than 80 ), a limited number of metabolic enzymes and even over 40 viruses use CK2 to phosphorylate essential proteins in their life cycle [6]. Experimental results clearly showed that CK2 is involved in regulation of transcription, translation, cell proliferation, survival and apoptosis [7]. Overexpression and overactivity of CK2 are associated with the development of neurodegenerative, inflammatory, cardio-vascular dis- eases, virus infections, and all the cancers having been examined $[8,9]$. Therefore, smallmolecular inhibitors of CK2 would be important compounds for the development of clinical agents.

In the previous work we have described chemical synthesis of the novel 5-hetarylamino- $1 H$-indazole derivatives as prominent inhibitors of human protein kinase CK2 [10]. Here we are representing measurements of their in vitro activity and SAR study as well as molecular docking simulation.

\section{Materials and Methods}

\section{Molecular docking}

Flexible docking was conducted using the program Autodock 4.2.6 [11]. The 3D structure of human protein kinase CK2 was obtained from the Brookhaven Protein Data Bank (PDB ID: 3 NSZ and 4UBA) [12, 13].

Water molecules, ions, and ligand were removed from the PDB file of the receptor. Ligands were prepared by Vega ZZ (command line) [14] and MGL Tools 1.5.6 [11]. To carry out a calculation with the aid of the Autodock program, the incoming formats of receptor and ligands data were converted into PDBQTformat with Vega ZZ in the AUTODOCK force field. This format contains the coordinates of the atoms and partial charges. Hydrogen atoms were removed from nonpolar adenine parameters: translation step $-2 \AA$, quaternion step 50 , torsion step -50 . Torsional degrees of freedom and coefficient were 2 and 0.274 , respectively. Cluster tolerance $-2 \AA$. External grid energy $-1,000$, max initial energy -0 , 
max number of retries $-10,000$. Number of individuals in the population -300 , the maximum number of energy evaluations $-850,000$, the maximum number of generations $-27,000$, number of top individuals, which survived to the next generation -1 , rate of gene mutation 0.02 , rate of crossover -0.8 , mode of crossover - arithmetic. Alpha parameter of Cauchy distribution was 0 , Beta parameter Cauchy distribution -1 . The number of iterations of the Lamarckian genetic algorithm was 50 for each ligand.

Visual analysis of the best-scored complexes was performed using Discovery Studio Visualizer 4.0 [Discovery Studio Visualizer: http://accelrys.com/].

\section{LogP calculation}

LogP values were calculated using Marvin Sketch 19.12 (https://www.chemaxon.com).

\section{Biological evaluation}

Compounds were tested using in vitro kinase assay [15]. Each test was carried out in triplicate in $30 \mu \mathrm{L}$ reaction volume, which contains $6 \mu \mathrm{g}$ of peptide substrate RRRDDDSDDD (New England Biolabs); 10 units of recombinant human CK2 holoenzyme (New England Biolabs); $50 \mu \mathrm{M}$ ATP and $0.05-0.1 \mu \mathrm{Ci}$ $\gamma$-labeled ${ }^{32} \mathrm{P}$ ATP; CK2 buffer $(20 \mathrm{mM}$ Tris$\mathrm{HCl}, \mathrm{pH} 7.5 ; 50 \mathrm{mM} \mathrm{KCl} ; 10 \mathrm{mM} \mathrm{MgCl}$ ) and inhibitor in varying concentrations. The incubation time was $20 \mathrm{~min}$ at $30^{\circ} \mathrm{C}$. The reaction was stopped by adding an equal volume of $10 \%$ orthophosphoric acid and the reaction mixture was loaded onto 20 -mm discs of phosphocellulose paper (Whatman). Disks were washed three times with $1 \%$ orthophosphoric acid solution, air-dried at room temperature and counted by the Cherenkov method in a beta-counter (LKB). As a negative control, an equal volume of dimethyl sulfoxide (DMSO) was added to the reaction mixture. Inhibition percentage was calculated as the ratio of substrate-incorporated radioactivity in the presence of inhibitor to the radioactivity incorporated in control reactions, i.e., in the absence of inhibitor. Serial dilutions of inhibitor stock solution were used to determine its $\mathrm{IC}_{50}$ concentration. The $\mathrm{IC}_{50}$ values represent means of triplicate experiments with SEM never exceeding $15 \%$.

\section{Results and Discussion}

Earlier we have found new promising CK2 inhibitors with $\mathrm{IC}_{50}$ values in a range 0.007 $0.1 \mu \mathrm{M}$ in in vitro assay with radiolabeled ATP [15] among the 4-substituted quinazoline derivatives of 5-amino-3-arylindazoles 1-3 [20]. We had left 3-(3,4-dichlorophenyl) substituent of the most active compound $\mathbf{1}$ unmodified and have focused on the variation of heterocyclic residue at the 5-position of indazole moiety [10].

A complex of compound 1 with a CK2 ATPbinding site is shown in Figure 1. An indazole heterocyclic moiety is involved in the hydrophobic interactions with amino acid residues Val66, Ile95, Phe113, Val116, Met163 and Ile174 in the adenine-binding region. Also, the indazole moiety forms a hydrogen bond with Val116 amino acid residue of the CK2 hinge region. The 3,4-dichlorophenyl substituent is directed towards the exit of ATP-binding pocket. It forms hydrophobic interaction with Leu45 and Met163. The (2-trifluoromethyl) quinazoline moiety lies inside the hydrophobic pocket I. It has hydrophobic interaction with 


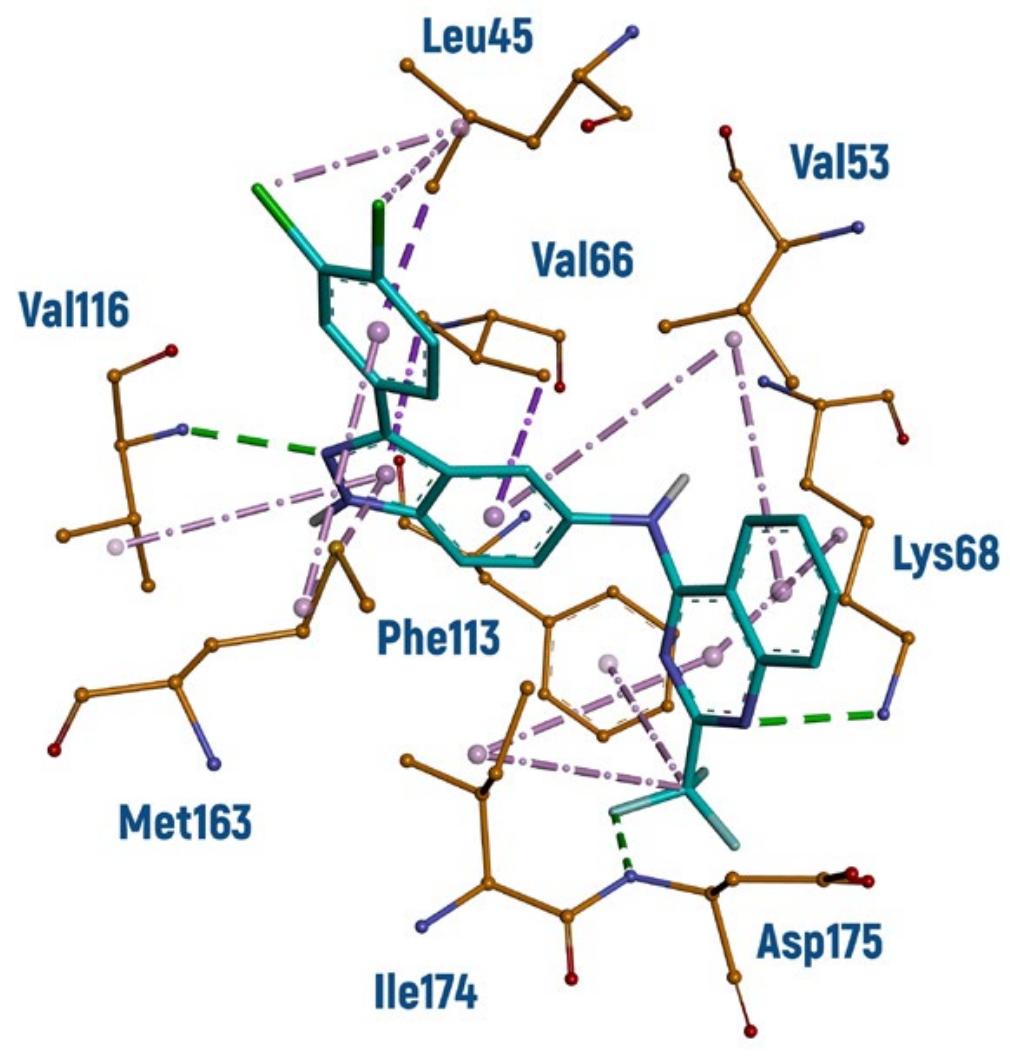

Fig. 1. Molecular modelling of the complex of compound 1 with human protein kinase CK2. Hydrogen bonds are indicated as green dashed lines and hydrophobic interactions - as magenta dot-dashed lines.
Phe113, Val53, Lys68 and Ile174. Additionally, 2-trifluoromethylquinazoline forms hydrogen bonds with Lys68 and Asp175.

Chemical structures, $\mathrm{IC}_{50}$, calculated $\log \mathrm{P}$ and $\operatorname{LipE}(\mathrm{CLOgP}$ and CLipE) values of the 14 new heterocyclic derivatives of substituted 5-amino-3-(3,4-dichlorophenyl)indazole are represented in the Table 1. In general, 5-amino3-aryl indazole derivatives show high inhibitory activity toward CK2 but mostly have had extremely high lipophilicity $(\log P>5)$. In this case, to estimate the efficiency of studied compounds as CK2 inhibitors, it was used a special composite parameter that linked inhibitory activity and lipophilicity parameter. This parameter is lipophilic efficiency or LipE [17].
LipE is the most "correct" [18] composed parameter, and it is determined using the following formula: $\mathrm{CLipE}=\mathrm{pIC}_{50}-\mathrm{Clog}$. The structure and $\mathrm{IC}_{50}$ values of the most effective studied inhibitors are shown in Table 2.

According to in vitro tests, 11 compounds (including 1-3 having been synthesized earlier) have submicromolar $\mathrm{IC}_{50}$ values ranging from $0.002 \mu \mathrm{M}(4)$ to $0.8 \mu \mathrm{M}(6)$. It turns out that negative steric influence of the bulky substituents at $2^{\text {nd }}$ position of quinazoline heterocycle on the compounds inhibitory activity is not as crucial as that of the substituents at the $6^{\text {th }}$ position. Small methyl group at the $6^{\text {th }}$ quinazoline's position of compound $\mathbf{8}$ causes decrease of $\mathrm{IC}_{50}$ by two orders of magnitude 
Table 1. Chemical structure, $\mathrm{IC}_{50}$, CLogP and CLipE of 5-amino-3-arylindazole derivatives.

\begin{tabular}{|c|c|c|c|c|c|c|c|c|c|c|c|}
\hline $\begin{array}{l}\text { Com- } \\
\text { pound }\end{array}$ & $\mathrm{R}_{1}$ & $\mathrm{R}_{2}$ & $\begin{array}{c}\mathrm{IC}_{50} \\
\mu \mathrm{M}\end{array}$ & $C \log \mathrm{P}$ & CLipE & $\begin{array}{l}\text { Com- } \\
\text { pound }\end{array}$ & $\mathrm{R}_{1}$ & $\mathrm{R}_{2}$ & $\begin{array}{c}\mathrm{IC}_{50} \\
\mu \mathrm{M}\end{array}$ & $C \log \mathrm{P}$ & CLipE \\
\hline \multirow[t]{2}{*}{1} & & & 0.007 & 7.5 & 0.5 & 9 & & & 8 & 6.7 & -1.6 \\
\hline & & & & & & 10 & & & 0.5 & 7.1 & -0.8 \\
\hline \multirow[t]{2}{*}{2} & & & 0.016 & 6.2 & 2.3 & & & & & & \\
\hline & & & & & & 11 & & & $>30$ & 6.1 & $<-1.6$ \\
\hline \multirow[t]{2}{*}{3} & & & 0.1 & 6 & 1 & & & & & & \\
\hline & & & & & & 12 & & & $>30$ & 7 & $<-2.5$ \\
\hline \multirow[t]{2}{*}{4} & & & 0.002 & 6 & 2.7 & & & & & & \\
\hline & & & & & & 13 & & & 3.5 & 5.9 & -0.4 \\
\hline \multirow[t]{2}{*}{5} & & & 0.015 & 7.6 & 0.2 & & & & & & \\
\hline & & & & & & 14 & & & 0.33 & 5.4 & 1.1 \\
\hline \multirow[t]{2}{*}{6} & & & 0.8 & 8.3 & -2.2 & & & & & & \\
\hline & & & & & & 15 & & & 0.8 & 4.6 & 1.5 \\
\hline \multirow[t]{2}{*}{7} & & & 0.18 & 8.9 & -2.1 & 16 & & & 0.004 & 5.4 & 3 \\
\hline & & & & & & 17 & & & 2.5 & 4.9 & 0.7 \\
\hline 8 & & & 0.5 & 6.5 & -0.2 & & & & & & \\
\hline
\end{tabular}


compared to the $\mathbf{4}$ with unsubstituted quinazoline ring. This decrease is even more than the decrease caused by the bulky 2-chlorophenyl residue of compound 7 . On the other hand, $2^{\text {nd }}$ position substituents having restricted dimensions cause almost no negative effect on compound activity - the $\mathrm{IC}_{50}$ of $\mathbf{1}$ and $\mathbf{5}$ with 2-trifluoromethyl and 2-isopropyl group is not far from the $\mathrm{IC}_{50}$ of 4 . The 4-phenylpyrimidine moiety of compound 9 in comparison to the quinazoline ring system of $\mathbf{4}$ probably have no enough hydrophobic interactions in ATPbinding site of $\mathrm{CK}-2$, as a result, the $\mathrm{IC}_{50}$ of 9 is more than one thousand times higher than the $\mathrm{IC}_{50}$ of 4 . However, the most surprisingly poor results in this testing were shown by quinoline derivatives $\mathbf{1 1}$ and $\mathbf{1 2}$ as well as thienopyrimidine thieno[2,3-d]pyrimidine derivative 13. 11 has almost the same geometry as 4 but shows no activity towards CK2. This might be a result of a combination of the lower basicity of quinoline heterocycle compared to quinazoline one and lower water solubility of 11. Difficulties with water solubility also may be a reason of significant variation in $\mathrm{IC}_{50}$ of more polar and hydrophilic pyrazolo[3,4-d] pyrimidine derivatives 14-17 which, according to $\mathrm{IC}_{50}$ compound 16 in $0.002 \mu \mathrm{M}$, can be active enough.

Regarging the lipophilicity - the analysis of FDA approved protein kinase inhibitors showed that average LipE value is 4.99 with a range from 2 (vandetanib) to 8.5 (tofacitinib) [19]. Our best compounds 2, 4 and $\mathbf{1 6}$ have values of CLipE 2.3, 2.7 and 3, respectively (Table 1). It is significantly lower than CLipE values of known promising CK2 inhibitors BFO13, FLC26, FNH79 and CX-4945-4.94, $3.85,4.48$ and 4.84 , respectively. Examined 5-amino-3-arylindazole derivatives have strong inhibitory potential toward CK2, but their physicochemical properties should be thoroughly optimized. In this case, the new 5-amino-3-arylindazole derivatives with the same binding mode and activities but with better CLipE values should be constructed.

The CLogP values of the most effective substituents $R_{1}$ and $R_{2}$ were calculated to determine the direction of optimization (see Figure 2).

$\mathrm{R}_{1}$ substituent [3-(trifluoromethyl)-1-quinazolyl] and $\mathrm{R}_{2}$ substituent 3,4-dichlorophenyl had the highest CLogP values - 2.6 and 3.6, respectively. These substituents were not taken into account for the design of the new 5-amino-3-arylindazoles.

Based on the SAR study, the results of molecular docking and calculated LogP values of each substituent, six new 5-amino-3-arylindazole derivatives were designed as possible effective human protein kinase CK2 inhibitors.

All new six compounds comply with Lipinski's rules. The structure and CLogP values of these compounds are represented in Figure 3.

The protein part of a crystal structure of the protein kinase CK2 complex with inhibi-

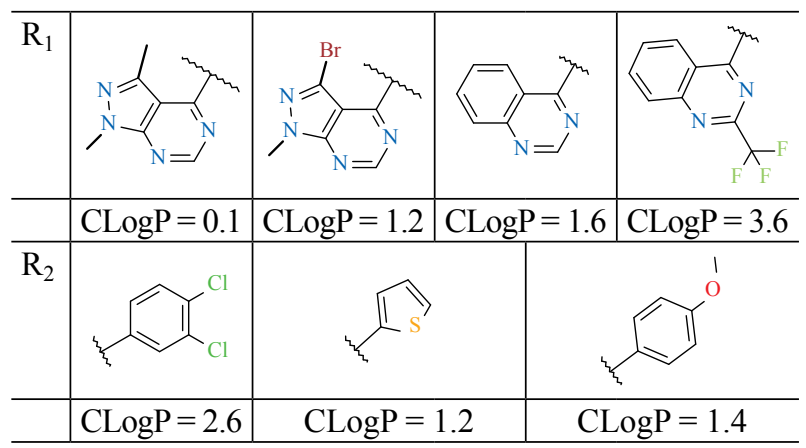

Fig. 2. Structure and $C \log P$ values of $R_{1}$ and $R_{2}$ substituents 
<smiles></smiles>

$$
\stackrel{18}{C L o g} \mathrm{P}=4.7
$$<smiles>c1csc(-c2n[nH]c3ccc(Nc4ncnc5ccccc45)cc23)c1</smiles>

$\stackrel{21}{\mathrm{CLog} P}=4.6$<smiles>COc1ccc(-c2n[nH]c3ccc(Nc4ncnc5c4c(C)nn5C)cc23)cc1</smiles>

19

$\operatorname{CLog} \mathrm{P}=3.3$<smiles>COc1ccc(-c2n[nH]c3ccc(Nc4ncnc5c4c(Br)nn5C)cc23)cc1</smiles>

$\stackrel{20}{C L o g} \mathrm{P}=4.1$<smiles>Cc1nn(C)c2ncnc(Nc3ccc4[nH]nc(-c5cccs5)c4c3)c12</smiles>

22

$\operatorname{CLogP}=3.2$<smiles>Cn1nc(Br)c2c(Nc3ccc4[nH]nc(-c5cccs5)c4c3)ncnc21</smiles>

23

$\mathrm{CLog} P=4.0$
Fig. 3. Structure and $C \log P$ values of new designed 5-amino-3-arylindazole derivatives

Table 2. Drug score values, molecular weight and the ratio of drug score value to molecular weight and numbers of heavy atoms of compounds.

\begin{tabular}{|c|c|c|c|c|c|c|}
\hline Compound & CLogP & $\begin{array}{c}\text { Number of } \\
\text { heavy atoms }\end{array}$ & MW & DrugScore & $\begin{array}{c}\text { DrugScore/ Number } \\
\text { of heavy atoms }\end{array}$ & DrugScore/MW \\
\hline FLC26 & $\begin{array}{c}3.9 \\
(\mathrm{CLipE}=3.85)\end{array}$ & 23 & 440 & $\begin{array}{c}-96 \\
\left(\mathrm{IC}_{50}=0.009 \mu \mathrm{M}\right)\end{array}$ & -4.2 & -0.22 \\
\hline BFO13 & $\begin{array}{c}3.5 \\
(\mathrm{CLipE}=4.94) \\
\end{array}$ & 22 & 362 & $\begin{array}{c}-86.2 \\
\left(\mathrm{IC}_{50}=0.0036 \mu \mathrm{M}\right)\end{array}$ & -3.9 & -0.24 \\
\hline CX-4945 & $\begin{array}{c}4.20 \\
(\mathrm{CLipE}=4.5) \\
\end{array}$ & 25 & 350 & $\begin{array}{c}-102 \\
\left(\mathrm{IC}_{50}=0.002 \mu \mathrm{M}\right)\end{array}$ & -4.1 & -0.29 \\
\hline 1 & $\begin{array}{c}7.5 \\
(\mathrm{CLipE}=0.5) \\
\end{array}$ & 32 & 571 & $\begin{array}{c}-115.1 \\
\left(\mathrm{IC}_{50}=0.01 \mu \mathrm{M}\right)\end{array}$ & -3.6 & -0.2 \\
\hline 2 & $\begin{array}{c}6.2 \\
(\mathrm{CLipE}=2.3) \\
\end{array}$ & 32 & 435 & $\begin{array}{c}-93.7 \\
\left(\mathrm{IC}_{50}=0.003 \mu \mathrm{M}\right)\end{array}$ & -2.9 & -0.22 \\
\hline 4 & $\begin{array}{c}6 \\
(\mathrm{CLipE}=2.7) \\
\end{array}$ & 28 & 495 & $\begin{array}{c}-98.5 \\
\left(\mathrm{IC}_{50}=0.002 \mu \mathrm{M}\right)\end{array}$ & -3.5 & -0.2 \\
\hline 16 & $\begin{array}{c}5.4 \\
(\mathrm{CLipE}=3) \\
\end{array}$ & 29 & 578 & $\begin{array}{c}-92.2 \\
\left(\mathrm{IC}_{50}=0.004 \mu \mathrm{M}\right)\end{array}$ & -3.2 & -0.16 \\
\hline 18 & 4.7 & 28 & 456 & -105.6 & -3.8 & -0.23 \\
\hline 19 & 3.3 & 29 & 385 & -105.3 & -3.6 & -0.27 \\
\hline 20 & 4.1 & 29 & 539 & -116.6 & -4 & -0.22 \\
\hline 21 & 4.6 & 25 & 424 & -79.4 & -3.2 & -0.19 \\
\hline 22 & 3.2 & 26 & 442 & -103.1 & -4 & -0.23 \\
\hline 23 & 4 & 26 & 507 & -96.3 & -3.7 & -0.19 \\
\hline
\end{tabular}



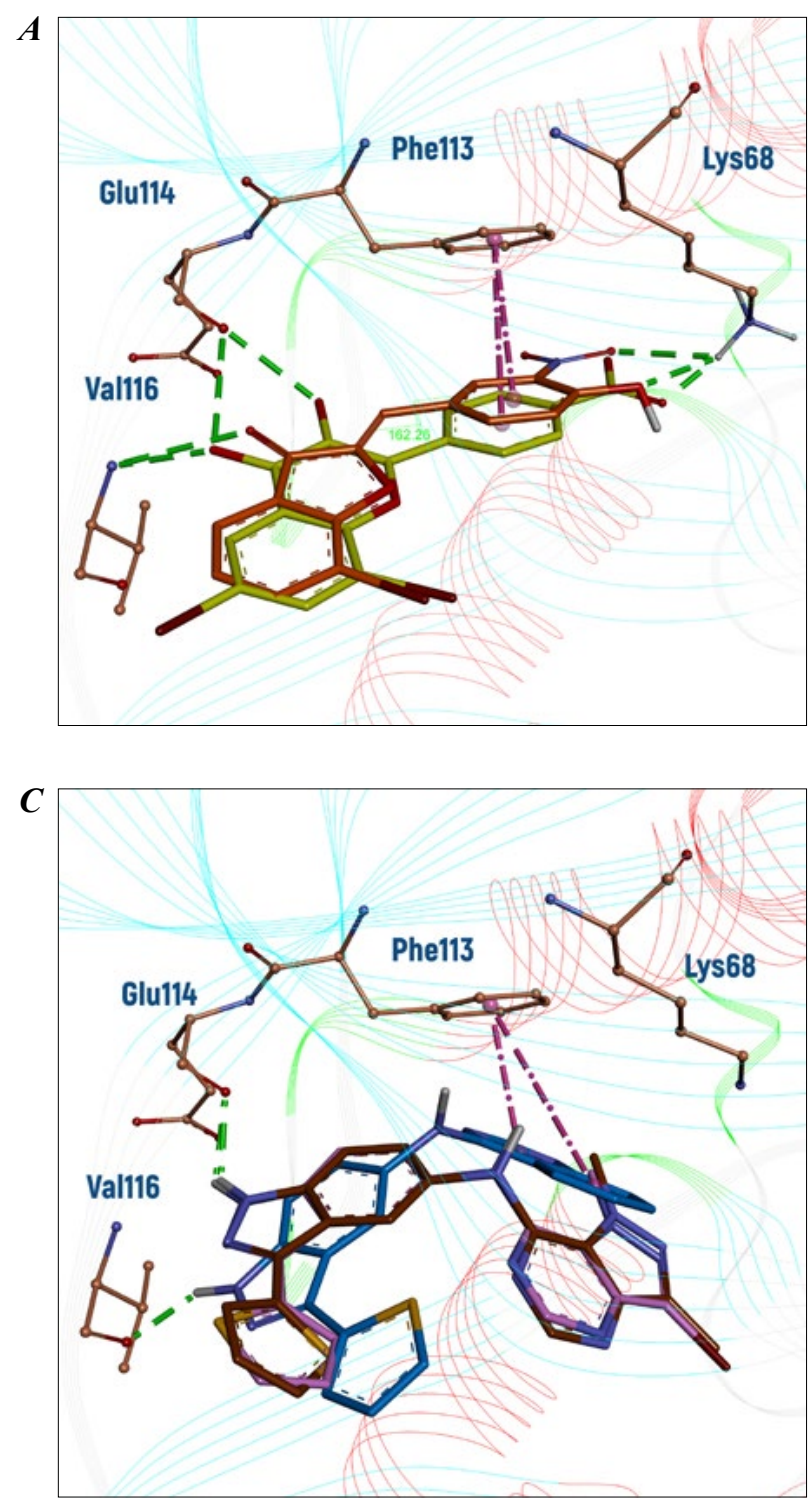

tor FLC26 (PDBID: 4UBA) was chosen as the target for docking studies and following comparison of docking scores of compounds 18-23 with known CK2 inhibitors FLC26, BFO13, CX-4945, 1, 2, 4 and 16. Score values were calculated using a knowledge-based scoring function Drug Score [20] (see Table 2).

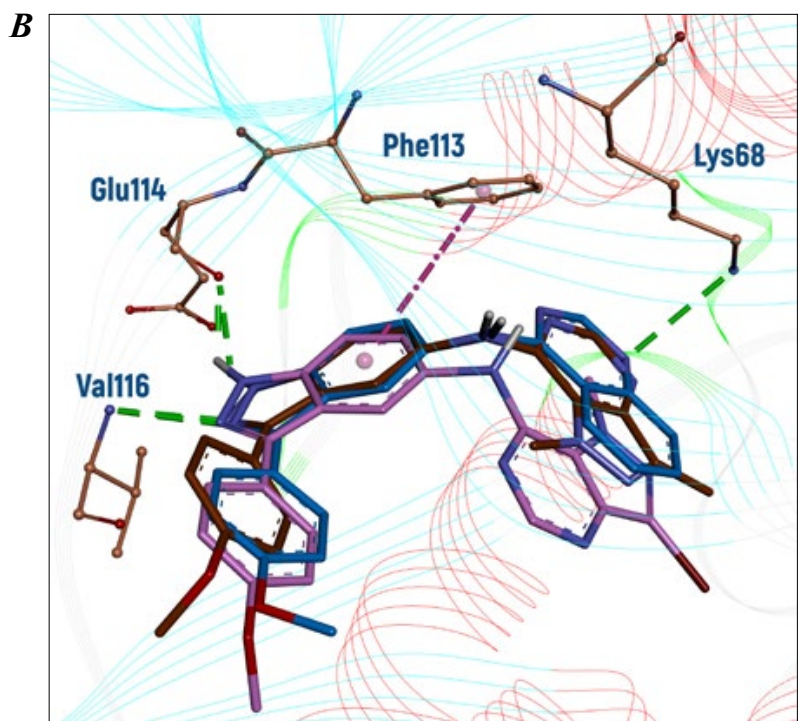

Fig. 4. Complexes of CK2 inhib itors FLC26 and BFO13 (A) and compounds 18-20 (B), 21-23 (C) with ATPbinding site of protein kinase CK2.

To avoid the influence of different molecular weights on the results of scoring function, the drug score values were approximated to molecular weights and numbers of heavy atoms of compounds. It is required for more detailed differentiation of its possible inhibitory activity. 
Molecular docking showed that binding modes of compounds 18-23 (see Figure 4) are similar to the binding mode of FLC26 proved by crystallography. $\mathrm{R}_{1}$ substituents are oriented to the hydrophobic pocket I and $R_{2}-$ to the exit of the ATP-binding pocket. Indazole heterocycle is located in an adenine-binding pocket and forms hydrogen bonds with hinge amino acid residues.

Among known inhibitors the compounds $\mathbf{1}$, CX-4945, compound 4, and FLC26 had the best Drug Score scoring function values $(-115.1,-102,-98.8,-96$ respectively), FLC26, CX-4945, BFO13 and compounds 1 - DrugScore/Number of heavy atoms coefficient $(-4.2,-4.1,-3.9,-3.6$, respectively) and CX-4945, BFO13, FLC26 and compounds 2 - DrugScore/Molecular weight coefficient $(0.29,-0.24,-0.22,-0.22$, respectively). Among designed compounds, compounds 20, 18 and 19 had the best Drug Score scoring function values $(-116.6,105.6$ and 105.3, respectively), compounds 20, 22 and 18 DrugScore/ Number of heavy atoms coefficient $(-4,-4$ and -3.8$)$, compounds 19,22 and 18 DrugScore/Molecular weight coefficient $(-0.27,-0.23$ and -0.23$)$. Taking into account CLogP, Drug Score scoring function, DrugScore/Number of heavy atoms and DrugScore/Molecular weight values, the best compounds for further development are $\mathbf{2 2}$ and 19. We anticipate that designed 5-amino-3-arylindazole derivatives will have lipophilic efficiency comparable with the best known CK2 inhibitors.

\section{Conclusions}

This research has demonstrated that 5-hetarylamino-3-arylindazoles have good potential as
CK2 inhibitors. Eleven compounds with submicromolar inhibitory activity were identified (compounds 4, 16 and 1 have shown $\mathrm{IC}_{50}$ values 2,4 and $7 \mathrm{nM}$, respectively). The binding mode of these compounds with CK2 was proposed using molecular docking methods. It demonstrates hydrogen bonds with aminoacids of the hinge region and numerous hydrophobic interactions which provide high activity of 5-amino-3-arylindazoles. SAR and docking studies allowed us to suggest lipophilic efficiency optimization methods and to design compounds with good probability to inhibit protein kinase CK2 for further development.

\section{REFERENCES}

1. Burnett $G$, Kennedy EP. The enzymatic phosphorylation of proteins. J Biol Chem. 1954;211(2):969-80.

2. Qiao $Y$, Chen $T$, Yang $H$, Chen $Y$, Lin $H, Q u W$, Feng F, Liu W, Guo Q, Liu Z, Sun H. Small molecule modulators targeting protein kinase CK1 and CK2. Eur J Med Chem. 2019;181:111581.

3. Poole A, Poore T, Bandhakavi S, McCann RO, Hanna DE, Glover CV. A global view of CK2 function and regulation. Mol Cell Biochem. 2005;274(12):163-70.

4. Niefind K, Pütter M, Guerra B, Issinger OG, Schomburg D. GTP plus water mimic ATP in the active site of protein kinase CK2. Nat Struct Biol. 1999;6(12):1100-3.

5. Bian $Y$, Ye $M$, Wang $C$, Cheng $K$, Song $C$, Dong $M$, Pan Y, Qin H, Zou H. Global screening of CK2 kinase substrates by an integrated phosphoproteomics workflow. Sci Rep. 2013;3:3460.

6. Meggio F, Pinna LA. One-thousand-and-one substrates of protein kinase CK2? FASEB J. 2003;17(3):349-68.

7. Hanks SK, Hunter T. Protein kinases 6. The eukaryotic protein kinase superfamily: kinase (catalytic) domain structure and classification. FASEB $J$. 1995;9(8):576-96. 
In vitro activity and SAR study of the novel hetarylamino-3-aryl-1H-indazole derivatives as inhibitors of protein kinase CK2

8. Wilson LK, Dhillon N, Thorner J, Martin GS. Casein kinase II catalyzes tyrosine phosphorylation of the yeast nucleolar immunophilin Fpr3. J Biol Chem. 1997;272(20):12961-7.

9. Faust M, Montenarh $M$. Subcellular localization of protein kinase CK2. A key to its function? Cell Tissue Res. 2000;301(3):329-40.

10. Protopopov MV, Vdovin VS, Lukashov SS, Ostrynska OV, Borysenko IP, Borovykov OV, Starosyla SA, Bilokin YV, Kukharenko OP, Bdzhola VG, Yarmoluk SM. The synthesis of 5-hetarylamino-3-aryl-1Hindazoles as inhi-bitors of protein kinase CK2. Biopolym Cell. 2020; 36(6):466-76.

11. Morris GM, Huey R, Lindstrom W, Sanner MF, Belew RK, Goodsell DS, Olson AJ. AutoDock4 and AutoDockTools4: Automated docking with selective receptor flexibility. J Comput Chem. 2009;30(16): 2785-91.

12. Ferguson AD, Sheth PR, Basso AD, Paliwal $S$, Gray K, Fischmann TO, Le HV. Structural basis of CX-4945 binding to human protein kinase CK2. FEBS Lett. 2011;585(1):104-10.

13. Guerra B, Bischoff N, Bdzhola VG, Yarmoluk SM, Issinger $O G$, Golub AG, Niefind K. A Note of Caution on the Role of Halogen Bonds for Protein Kinase/Inhibitor Recognition Suggested by High- And Low-Salt CK2 $\alpha$ Complex Structures. ACS Chem Biol. 2015;10(7):1654-60.

14. Pedretti A, Villa L, Vistoli G. VEGA--an open platform to develop chemo-bio-informatics applications, using plug-in architecture and script programming. J Comput Aided Mol Des. 2004;18(3):167-73.

15. Hastie CJ, McLauchlan HJ, Cohen P. Assay of protein kinases using radiolabeled ATP: a protocol. Nat Protoc. 2006;1(2):968-71.

16. Lukashov SS, Kukharenko OP, Bdzhola VG, Yarmoluk SM. Synthesis of 5-amino-3-arylindazole derivatives and study of their in vitro activity towards $\mathrm{Ser} / \mathrm{Thr}$ and Tyr protein kinases. V International Conference "Chemistry of Nitrogen Containing Heterocycles», Kharkiv. 2009:O.21.

17. Johnson TW, Gallego RA, Edwards MP. Lipophilic Efficiency as an Important Metric in Drug Design. J Med Chem. 2018;61(15):6401-6420.
18. Shultz MD. Setting expectations in molecular optimizations: Strengths and limitations of commonly used composite parameters. Bioorg Med Chem Lett. 2013;23(21):5980-91.

19. Roskoski $R J r$. Properties of FDA-approved small molecule protein kinase inhibitors. Pharmacol Res. 2019;144:19-50.

20. Neudert G, Klebe G. DSX: a knowledge-based scoring function for the assessment of protein-ligand complexes. J Chem Inf Model. 2011;51(10):2731-45.

\section{Визначення активності in vitro та аналіз співвідношення структура-активність нових гетероциклічних похідних 5-аміно-3-арил-1H- індазолу як інгібіторів протеїнкінази СК2}

М. В. Протопопов, В. С. Вдовін, С. С. Лукашов, О. В. Остринська, І. П. Борисенко, О. В. Боровиков, С. А. Старосила, Я. В. Білокінь, О. П. Кухаренко, В. Г. Бджола, С. М. Ярмолюк

Мета. Пошук нових інгібіторів протеїнкінази СК2 серед 5-гетариламіно- $1 H$-індазолів. Методи. Біохімічне тестування проводили in vitro за допомогою радіоактивно міченого $\gamma^{32} \mathrm{P}$ АТФ. Для молекулярного докінгу застосовували програмний пакет Autodock 4.2, рескоринг результатів докінгу виконували з використанням фукції скорингу DrugScore. Результати. Серед 17-ти похідних 5-аміно-3-ариліндазолу що було досліджено було знайдено 11 інгібіторів протеїнкінази СК2 $3 \mathrm{IC}_{50}$ в наномолярному діапазоні. Найбільш активна сполука мала $\mathrm{IC}_{50}=2$ нМ. Дослідження співвідношення структура-активність та додатковий молекулярний докінг цих сполук дозволив обрати перспективні модифікації для одержання нових сполук 3 кращими фізико-хімічними характеристиками. Висновки. В результаті проведеної роботи було отримано 11 нових наномолярних інгібіторів протеїнкінази СК2. Спираючись на результати молекулярного докінгу було запропоновано модель зв' язування цих молекул з АТФзв'язувальним сайтом кінази. На підставі аналізу фізико-хімічних характеристик та співвідношення структура-активність для замісників індазольного ядра досліджених сполук було запропоновано структури 6-ти нових похідних для подальшої розробки інгібіторів протеїнкінази СК2. Загалом 5-гетариламіно-1H- 
індазоли виявились вдалою основою для побудови нових інгібіторів протеїнкінази СК2.

Кл юч ов і с л ов а: інгібітор протеїнкінази CK2, тестування кіназної активності in vitro, молекулярний докінг, індазол, піразоло[3,4-d]піримідин.

\section{Определение активности in vitro и анализ соотношения структура-активность новых гетероциклических производных 5-амино-3- арил-1H-индазола в качестве ингибиторов протеинкиназы CK2}

М. В. Протопопов, В. С. Вдовин, С. С. Лукашов, О. В. Остринская, И. П. Борисенко, О. В. Боровиков, С.А. Старосила, Я.В. Белоконь, О. П. Кухаренко, В. Г. Бджола, С. М. Ярмолюк

Цель. Поиск новых ингибиторов протеинкиназы СК2 среди 5-гетариламино-1H-индазолов. Методы. Биохимическое тестирование проводили in vitro при помощи радиоактивно меченого $\gamma^{-32} \mathrm{P}$ АТФ. Для молекулярного докинга применяли программный пакет Autodock 4.2, рескоринг результатов докинга проводили с использованием фукции скоринга DrugScore. Результаты. Среди 17-ти исследованных производных 5-амино-3-арилиндазола было обнаружено 11 ингиби- торов протеинкиназы CK2 с $\mathrm{IC}_{50}$ в наномолярном диапазоне. У наиболее активного соединения $\mathrm{IC}_{50}=2$ нМ. Исследование соотношения структура-активность и дополнительный молекулярный докинг этих соединений позволил выбрать перспективные модификации для получения новых соединений с лучшими физико-химическими характеристиками. Выводы. В результате проведённой работы было получено 11 новых наномолярных ингибиторов протеинкиназы CK2. Опираясь на результаты молекулярного докинга была предложена модель связывания этих молекул с АТФсвязывающим сайтом киназы. На основе анализа физико-химических характеристик и соотношения структура-активность для заместителей индазольного ядра исследованных соединений были предложены структуры 6-ти новых производных для дальнейшей разработки ингибиторов протеинкиназы СК2. Вцелом 5-гетариламино- $1 H$-индазолы оказались удачной основой для синтеза новых ингибиторов протеинкиназы CK2.

К л юч е в ы е с л ов а: ингибитор протеинкиназы CK2, тестирование киназной активности in vitro, молекулярний докинг, индазол, пиразоло[3,4-d]пиримидин.

Received 05.11.2020 